DOI https://doi.org/10.18551/rjoas.2018-09.44

\title{
THE EFFECT OF SOFT COMPETENCY AND HARD COMPETENCY ON NURSE PERFORMANCE IN GENERAL HOSPITALS REGIONAL OF SIDOARJO
}

\author{
Febrinanda Deri \\ Department of Human Resource Development Program, University of Airlangga, Indonesia \\ E-mail: derifebrinanda@gmail.com
}

\begin{abstract}
This study aims to analyze the effect of Soft Competency and Hard competency on the performance given by nurses and analyze the effect of Soft competency and Hard competency together to the performance given by the nurse. Respondents in this research are some of the nurses in General Hospital of Sidoarjo are 120 people, with details of 24 people on 4 inpatient rooms (Tulip, Teratai, Mawar Kuning, Mawar Merah) and 1 outpatient room. Respondents were asked to complete the questionnaire to be given and give scores (assessments) on each item of question that had been made before. The results of the questionnaire were then analyzed statistically to assess the correlation of Soft Competency and Hard Competency on performance. Research on the influence of Soft Competency and Hard Competency on the performance of nurses at Sidoarjo Regional General Hospital was done by giving questionnaires to some 120 nurses to assess Soft Competency (Communication, Concern), and Motive, Hard Competency (Knowledge), Skill (Skill, Abilities) as well as nurse performance of Sidoarjo Regional General Hospital. The questionnaires given to nurses were then tested for validity and reliability with the help of computer statistics software (SPSS), as well as the partial or simultaneous relationship between Soft Competency (X1), and Hard Competency (X2), on nurses performance (Y). The results showed that there is a significant relationship between Soft Competency (X1), and Hard competency $(\mathrm{X} 2)$, on nurse's performance $(\mathrm{Y})$. This is seen from the $\mathrm{F}$ test and it is known that the sig F Count is 0,000 smaller than $\alpha=0.05$, then $\mathrm{H} 0$ is rejected and $\mathrm{H} 1$ is accepted. The result of multiple linear regression analysis shows the coefficient of determination (R2) the influence of Soft Competency and Hard Competency on the performance of nurse equal to 0,823 where there is $82,3 \%$ influence of independent variable to bound, For t-test of Soft Competency influence to nurse performance resulted sig 0,030 bigger $(<)$ than $\alpha=0.50$, which means no significant effect of Soft Competency on nurse performance. While for the ttest the influence of Hard Competency on the performance of nurses produced sig 0.000 smaller $(<)$ than $\alpha=0.50$, which means there is a significant Hard Competency influence on the performance of nurses, so it can be said that $\mathrm{H} 0$ rejected and $\mathrm{H} 1$ accepted simultaneously show Soft Competency and Hard Competency have a significant influence on nurse performance.
\end{abstract}

\section{KEY WORDS}

Soft competency, hard competency, performance, nurse, hospital, health service.

Health services are the basic rights of the community that must be fulfilled by the government, as explained in the Law of the Republic of Indonesia No. 36 of 2014 concerning Health Workers in considering paragraph B which reads "that health as a human right must be realized in the form of providing various health services to all the community through the implementation of comprehensive health development by the government, regional government and society in a directed, integrated, sustainable, fair and equitable manner, as well as safe, quality, and affordable by the community ". And also supported by Article $28 \mathrm{H}$ of the 1945 Constitution which reads: "Everyone has the right to live physically and mentally prosperously, to reside, and to have a good and healthy environment and the right to obtain health services" In accordance with the contents of the 1945 Constitution, the government is a servant the community, should provide good and quality health services to the community. 
The increasing life needs of the community at this time, the higher the public demand for the quality of health services provided by the government. In the midst of community efforts in the demands to improve the quality of health services that are increasingly high, hospitals must also begin to clean up. Medical services in hospitals are required to be more accountable, transparent, efficient, and also performance-based. So that there can be an increase in professionalism in the working environment. The hospital is no longer enough to only serve from the medical side, but must be able to provide comfort to patients and communities who need help.

Hospitals as professional health service organizations must be able to provide the best and quality services to consumers. in this case the community is the user of health services, whether as a patient or a family of patients. Building facilities are magnificent and accompanied by sophisticated medical equipment is not enough at this time to provide services that are expected by the community, in terms of performance to provide health services for the people authorized here are all medical personnel (doctors and nurses) who work in hospitals, services health that is more important now is to maintain patient safety consistently. The needs and expectations of the community for the service of skilled, good and friendly medical personnel are the expectations of the community and patients.

In providing quality service, every employee, both medical and non-medical, must show a friendly, polite and responsive attitude in realizing good service, and ready to help anyone without discrimination in the process of providing health services.

Health services in Indonesia provided by hospitals as government health service organizations to the public have not been maximized. There is still a lot of experience from a number of Indonesian people about the lack of good hospitals in that shows that so far hospitals in Indonesia have not been able to provide good health services, such as some real problems or reports from the public about the poor health services from hospitals in Indonesia. the authors compiled from mass media and the internet, many topics related to medical personnel or non-medical personnel in hospitals, for the example:

"However, not infrequently complaints are heard from RSUD patients in West Java regarding their medical services. These five hospitals that are summarized by PR have reaped the complaints of patients from 2016-2017".

"Dr. Soekardjo Tasikmalaya, the financial crisis of this hospital revealed, after the patient who was canceled, last January 14, 2017. Apparently, the Soekardjo Regional General Hospital experienced a drug vacuum, including anesthesia for surgery, due to debt arrears to drug distributors. Patients who canceled the surgery also complained about the cancellation of the operation so Zaihan (the patient) had to move to a private hospital - where treatment payments using the Health BPJS could not be served. Until the beginning of February 2017, Soekardjo Regional Hospital was still looking for a solution to the financial crisis experienced by the hospital that had been initiated since the 1920s".

"Soreang Regional Hospital, last February 2016, an introduction to the patient complained about the use of the hallway of the Soreang District Hospital in Bandung Regency, for hospitalization of patients. In addition, doctor visits to patients complained do not take place according to the applicable schedule.

"Cibabat Hospital, shocking news came from the Maternity Room in Cibabat Hospital, Cimahi City, 12 September 2016 early morning. Baby warmers suddenly explode before a patient will give birth. The patient was transferred to another room for childbirth. This year, at the age of 68, Cibabat Regional General Hospital continued to improve the quality of services and succeeded in achieving a certificate of graduation from the Five Star Plenary Accreditation from the Hospital Accreditation Committee.

"Bekasi City Hospital, Information is still not optimal service Bekasi City Hospital is not only obtained from patients who seek treatment there. But also from the mouth of the Mayor of Bekasi Rahmat Effendi, during a visit, October 18, 2016. Rahmat watched the queue of patients in the laboratory and the polyclinic was not well served due to the officers arriving too late.

"Karawang Hospital, last October 2016, two patients' families claimed to have been abandoned when registering for treatment at Karawang Hospital. Although he admitted that 
the patient's condition continued to decline, the patient was sent home under the pretext of "the condition is okay". Not long after, January 31, 2017 yesterday the bad news came back from the corridor of Karawang Hospital. Rosman, an introductory patient claimed that his relative Titih was sent away by security guards when he was going to seek treatment. Despite being evicted on the grounds that the room was full, Rosman continued to take Titih into the emergency room, which did not receive treatment until midnight. Titih died in waiting for the handling of medical personnel" (Source: http://www.pikiran-rakyat.com/jawabarat/2017/02/01/pelayanan-5-rsud-di-jabar-ini-pernah-dikomplain-pasien-392271).

Looking at the example of public complaints about the government health organization above, it could be that the community demanded better quality of health services, especially in hospitals as one of the government organizations that provide health services.

Hospitals are the main supporting facilities for providing health services to the community. In this case the hospital as one of the public service institutions in the health sector is required to be able to provide satisfying services for the community. In addition, hospitals are also required to improve the quality of their services continuously and continuously. Health care problems are often the main concern of the organization's management ranks. But if there is an attitude or behavior of hospital medical personnel who are less willing to patients, then this condition will create the impression that the hospital is still unable to meet the demands of the community. The quality of the hospital's health service to its patients is a very important thing, which in the end will be able to increase the level of satisfaction to the patients or the community, so that the function and goals of the hospital are expected to be achieved.

Identification of Problems. The role of human resources towards organizational development is more related to the performance displayed in carrying out their duties, obligations, and also the responsibility to manage the organization to be able to develop. Sidoarjo Regional General Hospital in Sidoarjo Regency as one of the government public service agencies seeks to achieve good public health services in the health sector, Sidoarjo Regional General Hospital is a reference from various regional hospitals in East Java with B accreditation or it can be said as a backup reference if Dr. Soetomo Surabaya General Hospital which is accredited $A$ as the main reference for various hospitals in East Java is full or unable to accommodate patients, then patients will be immediately referred to Sidoarjo Regional General Hospital.

In addition, the Sidoarjo Regional General Hospital is the main organization of health service providers in Sidoarjo Regency, East Java. To realize these values, the hospital management will strive to implement the basic values of public services into improving the quality of health services so that health services can be realized as expected by the people in need and also from hospital management, medical personnel or non-medical as a government organization in the health sector.

Table 1 - of Customer Satisfaction on the Performance of Sidoarjo Regional General Hospital in 2016

\begin{tabular}{|c|l|c|c|c|c|c|}
\hline No & \multicolumn{1}{|c|}{ Performance } & $\begin{array}{c}\text { Very } \\
\text { Dissatisfied }\end{array}$ & $\begin{array}{c}\text { Not } \\
\text { Satisfied }\end{array}$ & Satisfied & $\begin{array}{c}\text { Very } \\
\text { satisfied }\end{array}$ & Total \\
\hline 1. & $\begin{array}{l}\text { Suitability of action with a diagnosis } \\
\text { (Communication) }\end{array}$ & $0 \%$ & $7,5 \%$ & $57,5 \%$ & $35,0 \%$ & $100 \%$ \\
\hline 2. & Concern for patient's condition (Concern) & $0 \%$ & $2,7 \%$ & $73,0 \%$ & $24,3 \%$ & $100 \%$ \\
\hline 3. & Hospitality of service providers (motive) & $0 \%$ & $2.5 \%$ & $65,0 \%$ & $32,5 \%$ & $100 \%$ \\
\hline 4. & $\begin{array}{l}\text { Conformity information of medicines with } \\
\text { disease indications (Knowledge) }\end{array}$ & $4,3 \%$ & $4,3 \%$ & $73,9 \%$ & $17,4 \%$ & $100 \%$ \\
\hline 5. & $\begin{array}{l}\text { Alertness when performing medical actions } \\
\text { (Skills) }\end{array}$ & $0 \%$ & $12,5 \%$ & $75,0 \%$ & $12,5 \%$ & $100 \%$ \\
\hline 6. & $\begin{array}{l}\text { Speed of Responding to Customer } \\
\text { Complaints (Ability) }\end{array}$ & $0 \%$ & $4,8 \%$ & $85,7 \%$ & $9,5 \%$ & $100 \%$ \\
\hline
\end{tabular}

Source: Report of satisfaction and hope survey activities of blud patients of Sidoarjo District, 2016.

In the table above, there are some percentages that state that the community is not satisfied with some of the performance of the Sidoarjo Regional General Hospital, including 
the category of Soft Competency values and also Hard Competency. In the category of Soft Competency there are some percentages that show the community is very dissatisfied, for example in the case of Communication (Concern), and Motive (Motive) conducted by medical and non-medical officers who work in Sidoarjo Hospital.

While in the Hard Competency category, there are only a few percentages that show that the community feels very dissatisfied and dissatisfied with the values of the Skill, Knowledge and Ability categories owned by medical or non-medical staff. medical in carrying out health services to the community.

Competence is an individual's ability based on his knowledge and skills which are shown in thinking and acting in accordance with his field of work. Some employees, despite having high motivation, do not always have the ability or skills to play an important role in individual behavior and performance. (Gibson, Ivancevich, and Donnely, 2003) explain that there are three factors that affect performance, namely: a) individual factors, including abilities, skills, family background, work experience, social level, and demographic, b). psychological factors, including perception, role, attitude, personality, and job satisfaction, and c) organizational factors, including organizational structure, job design, leadership and reward systems.

Competence is an individual's ability based on his knowledge and skills which are shown in thinking and acting in accordance with his field of work. Some employees, despite having high motivation, do not always have the ability or skills to play an important role in individual behavior and performance. Along with the development of science and technology, there is also a change in the characteristics of society from a passive traditional attitude or an attitude of accepting what is changed to a demanding, opposing and parsitive attitude. Likewise with the demands of service by medical personnel in this case doctors and nurses who work in hospitals. The increasing number of patients who multiply over an unpredictable period of time causes the services of doctors and nurses to not be maximal all the time so the need for medical personnel in this case nurses to be able to master Soft competency and Hard competency properly, so that they are better able to deal with patients who need help every time and can be handled well and calmly. Based on the description above, this study will examine the problem of the influence of Soft Competency and Hard Competency on the performance of nurses at the Sidoarjo Regional General Hospital, East Java.

The formulation of the problem in this study are (1) Are Soft Competency and Hard Competency influential separately (partial) on the performance of nurses in Sidoarjo Regional General Hospital? (2) Does Soft Competency and Hard Competency together (simultaneously) affect the performance of nurses in Sidoarjo Regional General Hospital?

The purpose of this study was to analyze the influence of Soft Competency and Hard Competency on the performance of nurses at the Sidoarjo Regional General Hospital.

This research is expected to provide scientific information about the factors that affect the performance of nurses, namely: Soft Competency for example: Communication (Communication), Concern (Concern), and Motive (Motive). As well as Hard Competency for example: Knowledge, skills and abilities.

\section{LITERATURE REVIEW}

Competence is defined by Spencer \& Spencer, (1993) as the underlying characteristics of a person and is related to the effectiveness of individual performance in a job or in certain situations. (Individual underlying characteristic of an which is causally related to criterionreferenced effective and superior performance in a job or situation).

According to the Dharma S; (2002) in his book entitled "The New Paradigm of Human Resource Management" defines the words of Spencer \& Spencer (1993) above. that the underlying characteristics contain the meaning of competence which is a part of the personality that is profound and attached to a person and behavior that can be predicted in various circumstances and work assignments. While the word 'causally related' means that competence is something that causes or predicts behavior and performance. 
While the word 'criterion-referenced' means that the competency actually predicts who performs well and poorly, measured by the criteria or standards used. The determination of the required competency threshold will certainly be used as a basis for the selection process, succession of planning, performance evaluation and human resource development.

(Spencer \& Spencer, 1993) also explained that competencies that refer to characteristics in underlying behavior and describe motives, personal characteristics (characteristics), self-concept, values, knowledge or expertise brought by someone with superior performance (superior performer ) at workplace.

Competency levels have practical implications for human resources planning. In The Iceberg and Central and Surface Competencies theory proposed by (Spencer \& Spencer, 1993) illustrates that the competencies of the aspects of knowledge (knowledge competency) and expertise (skill competency) tend to be more visible and relatively on the surface as one characteristics possessed by humans. While self-concept (self-concept), trait (character / trait I nature) and motives (motives) competencies are hidden in and are at the central point of a person's personality so that it is more difficult to develop.

According to (Spencer \& Spencer, 1993), that competence can be divided into two categories, namely 'threshold' and 'differentiating' according to criteria used to predict the performance of a job. Threshold competency is the main characteristic (usually in the form of knowledge or basic skills such as the ability to read) that must be possessed by someone in order to carry out their work, for example again is the average threshold competency for a sales person is the product knowledge or ability to fill out forms.

"These are the essential characteristics (usually knowledge or basic skills, such as the ability to read) that everyone in a job needs to be minimally effective but not superior superior from average performers. A minimum competency for a salesperson is knowledge of the product or ability to fill out invoices ".

While differentiating competency are the factors that distinguish high-performing individuals and low-performing individuals. Someone who has a motivational orientation is usually considered in setting goals that exceed what the organization has set. For example, the competence of a highly motivated salesperson can set far more targets than a sales person whose performance is at an average level.

Based on the substance, competence is divided into two major groups, namely Soft Competency (general competence) and Hard Competency (field competence) (Masdar, Asmorowati, \& Irianto, 2009). Soft Competency is a competence that is closely related to the ability to manage work, relationships between people and also build interaction with others in the work environment and outside the work environment. Examples include leadership, communication, interpersonal relationships, and others. Basically, Soft Competency is a part that influences the development of one's Hard Competency and its performance. Like motives, innate factors and self-concept produce skills of expertise, then can produce performance and experience.

Based on the substance, competence is divided into two major groups, namely Soft Competency (general competence) and Hard Competency (field competence) (Masdar, Asmorowati, \& Irianto, 2009). Hard competency is a type of competency that is related to the functional or technical abilities of a job. Examples of understanding of the disease in health workers, the ability to diagnose / diagnose the disease being suffered by patients and others. Hard Competency is generally obtained during the education level, every employee who will or has just entered is always given certain education and training whose purpose is to improve skills and knowledge to suit the needs of the organization.

The increase in skill and knowledge is not enough, because many workers have above-average knowledge, but their behavior is not acceptable to their work environment, therefore more attention is needed to Soft Competency as a counterweight to be able to improve performance in organization.

Performance comes from the word "performance" which means achievement in the field of work, or the results of work performance shown to the organization where the individual works, according to (Mangkunegara AAP, 2006), performance is the work quality 
and quantity achieved by an employee in carrying out the assignment is in accordance with the responsibilities given.

In general, it can be said that performance is a measure of the success of an organization in achieving its goals. Individual performance (institutional performance) with institutional performance with corporate performance has a close relationship. In other words, if the employee's performance (individual performance) is good, then the probability of a corporate performance is also good. An employee's performance will be good if the individual has high skills, is willing to work due to salary or is paid according to the agreement when applying for a job and also has expectations (expectation) for a better future for himself and for the organization where he work.

Performance is the result of work achieved by a person or group of people in the organization in accordance with the authority and responsibility of each employee in an effort to achieve the goals of the organization legally, not violating the law and in accordance with morals and ethics.

In this study, what will be explained is the influence of Soft Competency and Hard Competency on the performance of nurses in Sidoarjo District Hospital. Based on theoretical studies and literature reviews that have been explained in the previous chapter, regarding Soft Competency, Hard Competency, and its effect on nurse performance, the following conceptual framework can be presented that serves as a guide, while reflecting the mindset for formulating hypotheses that will be researched and made. The conceptual framework of this research can be described as follows:

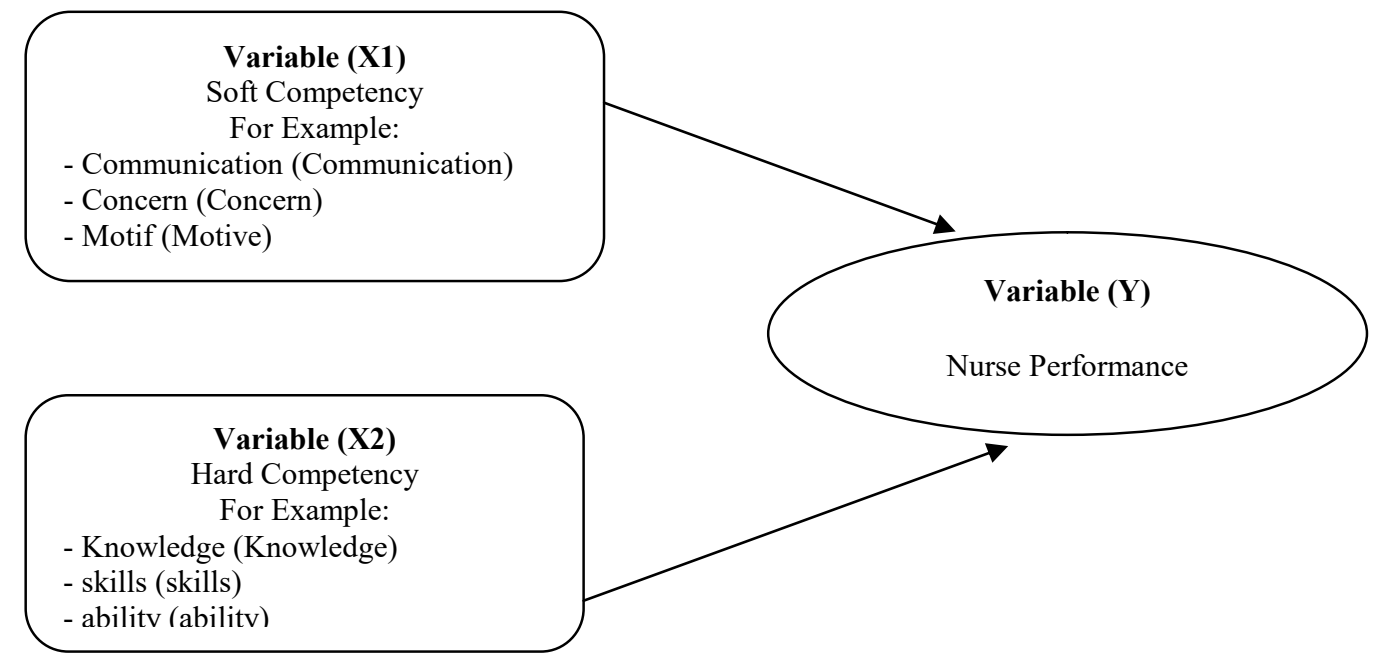

Figure 1 - Framework of study

The conceptual framework on the this page explains that the performance of nurses in hospitals that represent one of the government agencies in terms of public services in the field of health, cannot be separated from the elements of human resources, namely nurses as the subject of health care providers. The end result of a job will be good if it is in accordance with the standards set for a job. Every nurse as an individual has a different performance, this is most likely due to differences in situations and differences in competency characteristics (Soft Competency and Hard Competency) owned by each individual nurse.

Based on the description above, the following hypothesis can be proposed:

H1: Free Variables (Dependent), Soft Competency (X1) and Hard Competency (X2) have partial or separate effects on the dependent variable (Independent) of the performance of nurses $(Y)$ at Sidoarjo Regional General Hospital.

H2: Free variable (Dependent), Soft Competency (X1) and Hard Competency (X2) simultaneously or jointly affect the dependent variable (Independent) performance of nurse $(Y)$ in Sidoarjo Regional General Hospital. 


\section{METHODS OF RESEARCH}

In accordance with the objectives to be achieved in this study is to explain the effect of several variables that have been determined, then this type of research is explanative research (explanation research) that is looking at the influence between research variables and testing the hypotheses that have been formulated in the previous chapter.

Based on the formulation of the problem and the research hypothesis, the data collected in this study will be analyzed using Multiple Rank Regression by applying the following formula:

$$
Y=a+b 1 X_{1}+b 2 X_{2}+\ldots
$$

Where: $\mathrm{Y}=$ Nurse Performance; $\mathrm{a}=$ constant; $\mathrm{X} 1=$ Soft Competency; $\mathrm{X} 2=$ Hard Competency; b1, b2 = coefficient.

This statistical test is used to analyze and calculate the effect of several independent variables on one dependent variable with ordinal scale data. The software used to manage the data that has been answered by the respondent is IBM SPSS Statistics Version 23.

In this research will be carried out the sampling method because the population is too much or the range is too broad so it is not possible to take data on the entire population, therefore the sampling method used is random sample method, which is sampling technique that mixes subjects in in the population so that all subjects are considered equal. The population in this study were nurses at Sidoarjo Regional General Hospital. Currently Sidoarjo Regional General Hospital has a total of 635 nurses (as of June 2018) and the nurses are spread from 4 parts of the Inpatient Room and 1 poly room. outpatient, according to the research offices of the Sidoarjo Regional General Hospital totaling 120 nurses, consisting of 24 nurses in Tulip, Teratai, Mawar Kuning, Mawar Merah inpatient rooms, and also outpatient poly rooms.

Data collection in this study was carried out in the following ways: (a). Questionnaire, which is data collection by giving questionnaires to objects studied in Sidoarjo Hospital to obtain data about all variables to be studied. Namely: nurse discipline, nurse competency and nurse performance in accordance with the items in the questionnaire, (b). review the report / document published by Sidoarjo District Hospital in relation to the variables to be studied.

Each research variable each has 25 questions which include all variable members from Soft Competency (X1) 25 items, Hard Competency (X2) 25 items, and also Performance (Y) 25 items so the total questions in the questionnaire total 75 questions .

Determination of scores on each variable using a Likert scale model, with five answer choices, where each answer gets a score between 1-5, the choice of answers strongly disagree (STS) get a score of 1 , and very agree (SS) answer choices get a score of 5 . Increasingly the high score obtained by the subject, the higher the variables answered by the nurse.

To further clarify what variables will be examined, the concept and definition of each variable can be explained briefly as follows:

- Soft Competency (X1), namely the general ability to manage the work process between fellow human beings (Empathy) and use skills outside technical and academic skills, and prioritize intra and inter personal skills. Intra-personal skills include self-awareness (self-confidence, self-assessment, traits and preferences, and emotional awareness) and self-skills (self-control, resource management, proactive behavior). In this research thesis the high and low general competencies of nurses in this study are measured by their ability to complete the work / tasks they carry out, both technical and non-technical by using the variables of Communication (Concern), and Motive (Motive ) The more competent a nurse is, the higher the score he gets, and vice versa.

- Hard Competency (X1), is the ability of individual basic fields in mastering or carrying out a job and the ability to analyze work or work regulations. The high and low 
competencies that nurses have in this study are measured by their ability to complete the work / tasks they carry out, both technical and non-technical, both by using their skills, knowledge and abilities. The more competent a nurse is, the higher the score he gets, and vice versa.

- Nurse Performance $(\mathrm{Y})$, is the achievement of work or the work of nurses in carrying out the tasks given in accordance with predetermined work standards. The dimensions of nurse performance in this study include: work quality, work quantity and timeliness in completing work. The higher the nurse's performance is shown the higher the quality, quantity, and accuracy of the nurse's work time. Conversely, low yeng scores also show low performance.

Validity test on Soft Competency variable (X1) there are 2 questions that are invalid or invalid because it has a number $r$ less than $>0.30$ (Sugiyono, 2011), while the validity test on Hard Competency variable (X2) and Nurse Performance Variable (Y) is not There is a question item that is dropped and declared valid. For Reliability Test with SPSS Software version 23, Soft Competency variable (X1) gets Cronbach Alpha number of 0.926, Hard Competency variable (X2) gets Cronbach Alpha number of 0.950 , and Nurse Performance Variable $(Y)$ gets Cronbach Alpha number of 0.946, then it can be concluded that the items that measure the research variables are reliable because the Cronbach Alpha numbers obtained by these three variables are more than the size of the reliability test criteria $>0.60$ (Sugiyono, 2011).

Table 2 - Reliability Test for All Research Variables

\begin{tabular}{|c|c|c|c|c|}
\hline Variables & Item & Cronbach Alpha & Information & Keterangan \\
\hline Soft Competency (X1) & $23 / 25$ & 0.926 & 0.60 & Reliable \\
\hline Hard Competency (X2) & $25 / 25$ & 0.950 & 0.60 & Reliable \\
\hline Kinerja (Y) & $25 / 25$ & 0.946 & 0.60 & Reliable \\
\hline
\end{tabular}

To find out whether the resulting regression model is a regression model that produces a linear estimator is not the best bias, it is necessary to test the classical deviation symptoms.

Before testing the hypothesis using multiple linear regression, it is necessary to test the classical assumption as a requirement in the analysis so that the data can be meaningful and useful. According to Lubis et.al (2007) in making a classic assumption test must use the data to be used in the regression test. The Classic Assumption test used includes normality test, multicollinearity test, autocorrelation test, and heterokesdasticity test.

Multiple linear regression analysis is used to answer the third hypothesis knowing the effect simultaneously between the independent variables (X1 and $X 2)$ with the dependent variable $(Y)$ using the t-test (Partial) and $F$ Test (Simultaneous). The multiple linear regression analysis equation is as follows:

$$
Y=\alpha+\beta 1 X 1+\beta 2 X 2
$$

Criteria for acceptance and rejection of hypotheses if:

- Value of $F$ count $>F$ table, or significant $F \leq 0.05$, then the null hypothesis $(\mathrm{H} 0)$ is rejected and the alternative hypothesis $(\mathrm{Ha})$ is accepted;

- Value of $F$ counts $\leq$ Ftable, or significant $F>0.05$, then the null hypothesis $(\mathrm{HO})$ is accepted and the alternative hypothesis $(\mathrm{Ha})$ is rejected.

Umar (2000) states that the coefficient of determination (R2) essentially measures the extent of the ability of the regression model to explain the variation of the dependent variable.

\section{RESULTS AND DISCUSSION}

This research was conducted at Sidoarjo Regional General Hospital which is located at Jl. Mojopahit No.667, Celep, Kec. Sidoarjo, Sidoarjo Regency, East Java. This research was carried out in June-July 2018. The nurses were spread from 4 parts of the Inpatient Room 
and 1 outpatient poly room, according to the research offices of the Sidoarjo Regional General Hospital (attachment) totaling 120 nurses consisting , with details of 24 nurses in Tulip, Teratai, Mawar Kuning, Mawar Merah, and also outpatient poly rooms.

Data in the form of perception of the answers of nurses as research respondents regarding Soft Competency factors (X1), Hard Competency (X2), and Nurse Performance (Y) collected from questionnaires, are then tabulated in the attachment. From the data that has been collected then the average value of each item (item) is sought to find out the actual situation in the field.

With a class interval of 0.8 , then the average assessment criteria for respondents' answers are presented in the table below:

Table 3 - Mean Category of Interval Score

\begin{tabular}{|c|c|c|}
\hline Interval & Kategori & Nilai \\
\hline $4.20-5.00$ & Very Good & 5 \\
\hline $3.41-4.20$ & Good & 3 \\
\hline $2.61-3.40$ & Pretty Good & 2 \\
\hline $1.81-2.60$ & Not Good & 1 \\
\hline $1.00-1.80$ & Not Very Good & \\
\hline
\end{tabular}

After conducting a series of tabulation and cooding activities on the answers of the questionnaires distributed, the results showed that the respondents' assessment of all questions and the mean mean were categorized as very good, found in the table below:

Table 4 - Respondents' Assessment

\begin{tabular}{|c|c|c|c|c|}
\hline No & Variable & Item Pertanyaan & Mean Value & Category \\
\hline 1 & Soft Competency $(\mathrm{X} 1)$ & 25 & 4,40 & Very Good \\
\hline 2 & Hard Competency $(\mathrm{X} 2)$ & 25 & 4,53 & Very Good \\
\hline 3 & Kinerja $(\mathrm{Y})$ & 25 & 4,43 & Very Good \\
\hline \multicolumn{2}{|c|}{ Total } & 75 & & \\
\hline
\end{tabular}

Multicollinearity shows the occurrence of a strong correlation between the independent variables in the model. A good model must be free of multicollinearity. To detect multicollinearity tolerance and VIF values are used, if the tolerance value is $>0.10$ or VIF $<10$ (Nugroho, 2005), then the model is free from multicollinearity. The following is a multicolinearity test on the regression model:

Table 5 - Multicollinearity Test / Variance Inflation Factor (VIF) Results

\begin{tabular}{|c|c|c|}
\hline \multirow{2}{*}{ Variables } & \multicolumn{2}{|c|}{ Colinierity Statistics } \\
\cline { 2 - 3 } & Tolerance & VIF \\
\hline Soft Competency $\left(\mathrm{X}_{1}\right)$ & 0,177 & 5,641 \\
\hline Hard Competency $\left(\mathrm{X}_{2}\right)$ & 0,177 & 5,641 \\
\hline
\end{tabular}

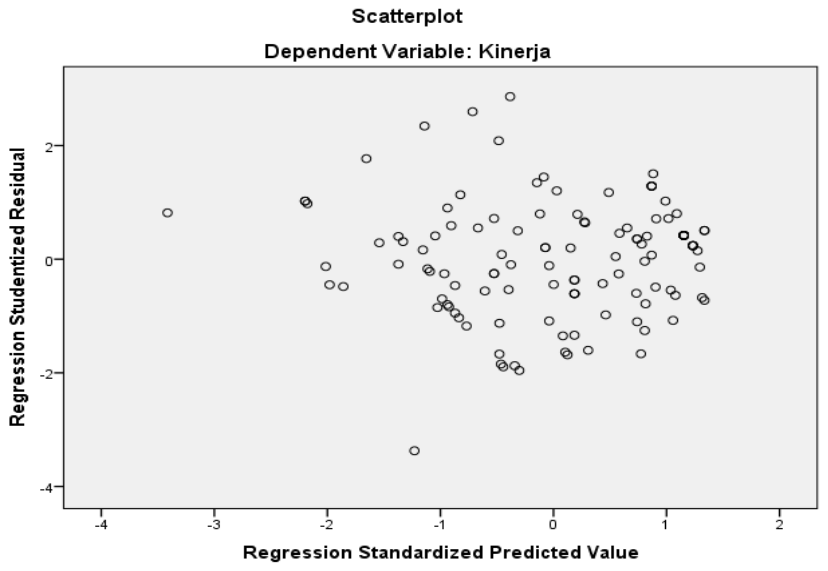

Figure 2 - Heterocedasticity test 
Based on the table above, it is known that the independent variable in the regression equation model has a tolerance value $>0.10$ and VIF $<10$, thus concluded that the two independent variables in the regression model are free of multicollinearity problems.

Heterocedasticity test is done to find out homogeneous or not research sample variables, it can be seen in the scatter plot image below which shows that the items of questions have spread irregularly and also indicates that the regression model can be free from the assumption of heteroscedasticity.

A good model must have a residual that is normally distributed. To test the residual normality, test is used with a normal graph of probanility plot. If the normal probability graph of the plot has spread around the diagonal line, then the regression model generated has a normal distribution, the following is the result of the normality test in the regression equation model:

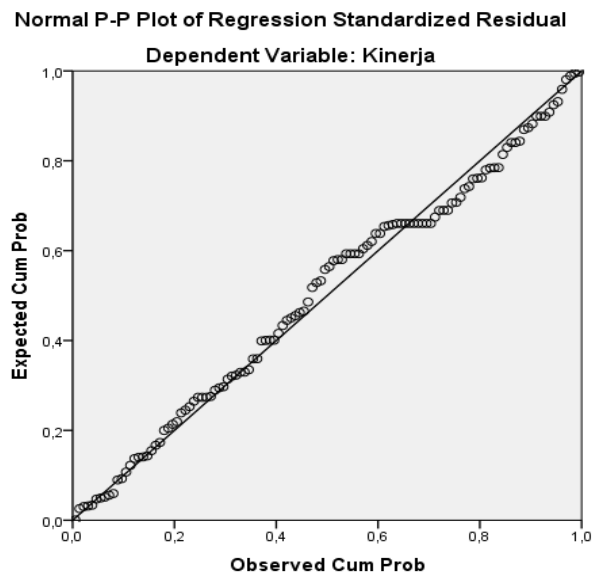

Figure 3 - Normal Image Probability Performance Plots

In the normal probability plot graph for the regression equation model, it appears that it has spread around the diagonal line, so it can be concluded that the residual regression equation model has been normally distributed.

Table 6 - Kolmogorov-Smirnov Test Table

\begin{tabular}{|l|c|c|}
\hline \multirow{2}{*}{ Residual Regression Model } & \multicolumn{2}{|c|}{ One Sample K-S } \\
\cline { 2 - 3 } & K-S Z & Sig \\
\hline Residual Regression Model & 0,200 & 0,997 \\
\hline
\end{tabular}

Based on the table, it can be seen that the test results with Kolmogorov-Smirnov show that the significance value ( $p$-value) is greater than 0.05 , which means that the residual regression equation model has been normally distributed.

In a good regression model the residuals generated in each equation cannot be interconnected with other observations. If the results of the Durbin Watson test result in a value that is in the range du to (4-du) then the assumption of autocorrelation has been fulfilled. Here are the results of the autocorrelation test on the regression equation model:

Table 7 - Durbin WatsonTest Table

\begin{tabular}{|c|c|c|c|}
\hline \multirow{2}{*}{ Variable } & \multicolumn{3}{|c|}{ Durbin Watson Test } \\
\cline { 2 - 4 } & $\mathrm{Du}$ & $\mathrm{Dw}$ & (4-du) \\
\hline Residual Regresision & 1.736 & 1.942 & 1.946 \\
\hline
\end{tabular}

Based on table test-t can be seen that the results of the durbin watson autocorrelation test obtained from the residual regression have been in the range du to (4-du) no more and less which means that the regression equation produced is free from the assumption of autocorrelation. 


\section{DISCUSSION OF RESULTS}

Table 8 - Table of Results of Multiple Linear Regression Analysis of Free Variables to Variables Bound to Nurse Performance

\begin{tabular}{|c|c|c|c|c|}
\hline Variables & Regression Coefficient & $t$ & Sig. $t$ & Correlations Partial \\
\hline Konstanta $(\alpha)$ & 5,256 & 1,161 & 0,248 & \\
\hline Soft Competency $\left(\mathrm{X}_{1}\right)$ & 0,185 & 2,200 & 0,030 & 0,199 \\
\hline Hard Comptency $\left(\mathrm{X}_{2}\right)$ & 0,932 & 23,402 & 0,000 & 0,840 \\
\hline $\mathrm{R}$ & 0,987 & & & \\
\hline R.Square & 0,823 & & & \\
\hline F Calculate & 547,648 & & & \\
\hline Sig F Calculate & 0,000 & & & \\
\hline
\end{tabular}

Model of Multiple Linear Regression in this study:

$$
Y=5,256+0,185 X_{1}+0,932 X_{2}
$$

Hypothesis of the influence of independent variables partially on the bound variable. To prove the effect of partially independent variables on the dependent variable, see the statistical value in the table above the multiple linear regression model, it is known that the value of $t$ counts as follows:

- Effect of Soft Competency (X1) on performance $(Y)$ is known that the value of t count is known that the calculated value is 2.200 , thus because the significance value of 0.030 is greater than 0.05 , it can be concluded that Soft Competency does not have a significant positive effect towards performance.

- The influence of Hard Competency (X2) on performance $(\mathrm{Y})$ is known that the calculated $t$ value is 0.932 with a significance value of 0.000 . thus because the significance value of 0,000 is less than 0.05 , it can be concluded that Hard Competency has a significant positive effect on performance

From the results of the $t$ test for each influence of the independent variables (Soft competency and Hard Competency) the significant effect is only Hard Competency variables (X2).

So it can be concluded that the hypothesis I which states the Hard Competency variable which consists of factors Skill, Knowledge, and Ability partially only Hard Competency variables (X2) which have a significant effect on the performance of nurses in Sidoarjo Regional General Hospital can be verified.

From the results of table 5.16 the correlation coefficient on variable X2 is Hard Competency which has the highest partial correlation value of 0.840 when compared to other independent variables, namely Soft Competency (X1) of 0.199 , the Hard Competency variable is the most dominant independent variable affecting the dependent variable partial, namely the performance of nurses in Sidoarjo Regional General Hospital.

Hypothesis of the influence of Free Variables (X1 \& X2) Together Against the Bound Variables (Test F). Based on the statistical values in the table above the results of multiple linear regression analysis, to prove the effect of Soft Competency and Hard Competency on performance is known that the calculated $F$ value is 547,648 with a significance value of 0,000 . Thus because the significance value of 0,000 is smaller than 0.50 , it can be concluded that Soft Competency (X1) and Hard Competency (X2) have a significant influence on the performance of nurses.

From the results of the $\mathrm{F}$ test above, it can be concluded that $\mathrm{HO}$ is rejected and $\mathrm{H} 1$ is accepted, thus the first hypothesis of the research is shouted, in other words the variable Soft Competency and Hard Competency simultaneously have a significant effect. So it can be concluded that hypothesis II which states Soft Competency and Hard Competency simultaneously or together can have a significant effect on the performance of nurses in Sidoarjo Regional General Hospital can be proven true. 


\section{CONCLUSION}

Based on the results of the analysis and testing hypotheses, some conclusions can be drawn as follows:

The results of the analysis on the regression testing of the influence of Soft Competency on the performance of nurses at Sidoarjo Regional General Hospital showed that there was no significant influence on the performance of nurses. This is known from the results of the analysis where between Soft Competency and nurse performance obtained the regression coefficient number of 0.185 with sig: $0.030(P>0.50)$.

The results of the analysis on the regression testing of Hard Competency influence on the performance of nurses in Sidoarjo Regional General Hospital shows that there is a very significant influence on the performance of nurses. This is known from the results of the analysis where between Hard Competency and nurse performance obtained the regression coefficient number of 0.932 with sig: 0.000 ( $P>0.50$ ).

The results of regression analysis show that the two independent variables X1 (Soft Competency) and X2 (Hard Competency) simultaneously / together have a very significant influence on the dependent variable $Y$ (Nurse Performance) with a multi correlation coefficient $R=0.932$. The coefficient of determination $R 2=0.932$ explains that $93.2 \%$ of the variance in nurse performance is explained by the variables of Soft Competency and Hard Competency. While $6.8 \%$ is explained by error variance, or by other variables not observed in this study. Partially the Hard Competency variable (X2) has the most dominant influence of the two independent variables on the performance of nurses, with a partial coefficient of 0.932. On the other hand, the variable Soft Competency (X1) is because the correlation coefficient is small, statistically it does not give significant influence, so the effect on the nurse's performance is not taken into account.

\section{SUGGESTIONS}

The researcher realizes that the results of this study still cannot provide an adequate picture of the influence of Soft Competency and Hard Competency on the performance of nurses at Sidoarjo Regional General Hospital, due to the limitations of researchers. The suggestions for related parties as well as for further research are as follows:

- Development of human resources in a hospital that focuses primarily on health services, desperately needs resources that have adequate competence. For this reason the author hopes that the hospital will always develop competence for its employees, both technical, administrative and social, which is expected to help make employees' performance even better in providing health services to the public.

- Hospitals as public organizations in the field of health-based services that serve, it will require human resources who have adequate competence for each level. Therefore, it is hoped that the hospital can develop the competence of its human resources in the hope that it can provide quality health services and always be proactive towards people who need help.

- Even though the Society pays for treatment or health services using BPJS (Health Social Security Administering Agency) and is willing to queue with other patients. It does not mean that health services can be overextended, it is better to complete the service quickly and well with hope even though the assumption that governmentowned hospitals can be considered capable of working professionally is like a private hospital that tends to be expensive, but fast.

\section{REFERENCES}

1. Dharma, S. (2002). Paradigma Baru Manajemen Sumber Daya Manusia. Yogyakarta: Amara Books. 
2. Gibson, James L., John M.Ivancevich, James H.Donnely Jr., \& Robert Konopaske. (2003). Organizations, Behavior, Structure, and Process, New York. The McGraw-Hill Irwin.

3. Masdar, Asmorowati, \& Irianto. (2009) Manajemen Sumber Daya Manusia Berbasis Kompetensi untuk pelayanan publik. Airlangga University Press.

4. Mangkunegara, A. A. P. (2006). Perencanaan dan Pengembangan SDM. Bandung: PT Refika Aditama.

5. Nugroho, Bhuono Agung. (2005). Strategi Jitu Memilih Metode Statistik Penelitian dengan SPSS. Edisi 1. Yogyakarta: Andi.

6. Spencer, Signe M. dan Spencer Lyle M. (1993). Competence at Work Model For Superior Performance. Canada: Library of Congress cataloging.

7. Sugiyono. (2011). Metode Penelitian Pendidikan Pendekatan Kuantitatif dan Kualitatif dan R\&D. Bandung: Alfabeta.

8. Umar, Husein. (2000). Riset Sumber Daya Manusia. Edisi Revisi. Jakarta: PT. Gramedia Pustaka Utama.

9. Irianto, Jusuf. (2001). Prinsip - Prinsip Dasar Manajemen Pelatihan: dari Analisis Kebutuhan Sampai Evaluasi Program Pelatihan. Surabaya: Insan Cendekia.

10. Lubis, Ade Fatma dan Syahputra, Adi. (2007). Pedoman Penulisan Proposal dan Tesis, Medan: Progam Magister Akuntansi Sekolah Pascasarjana USU.

11. Republic of Indonesia Law No. 36 of 2014 concerning Health Workers \& Article $28 \mathrm{H}$ of the 1945 Constitution. 